\title{
Social Media Marketing of Higher Education in Africa: Perspectives from Facebook
}

\author{
Kehdinga George Fomunyam \\ Teaching and Learning Development Centre, Mangosuthu University of Technology, South Africa
}

Received May 31, 2020; Revised September 5, 2020; Accepted October 30, 2020

\section{Cite This Paper in the following Citation Styles}

(a): [1] Kehdinga George Fomunyam, "Social Media Marketing of Higher Education in Africa: Perspectives from Facebook," Universal Journal of Educational Research, Vol. 9, No. 3, pp. 693 - 701, 2021. DOI: 10.13189/ujer.2021.090329.

(b): Kehdinga George Fomunyam (2021). Social Media Marketing of Higher Education in Africa: Perspectives from Facebook. Universal Journal of Educational Research, 9(3), 693 - 701. DOI: 10.13189/ujer.2021.090329.

Copyright $\mathrm{O} 2021$ by authors, all rights reserved. Authors agree that this article remains permanently open access under the terms of the Creative Commons Attribution License 4.0 International License

\begin{abstract}
Social media can be referred to as a group of internet-based applications that build on the ideological and technological foundations of Web 2.0, and allow the creation and exchange of user-generated content as well as interactive discussion. This article examines marketing in tertiary institutions in Africa using social media, but focuses on Facebook. Exploring the importance of social media marketing as a channel of communication to maximize an institution's appeal to its target audience, this paper seeks to present its importance in tackling competitive challenges and ensure the alignment of goals and resources. Most African higher educational institutions (HEIs) have adopted Facebook as the key instrument in social media marketing, with the intent of projecting a superior brand for the purpose of interacting with alumni, current students, attracting prospective applicants and ultimately increasing enrolment numbers. AI, Automation $\&$ AR, retargeting, automation tools and virtual tours are just some of the new and emerging tools and applications that are explored on Facebook by HEIs as a means of building new relationships and fostering existing ones. This study analysed data from 10 higher institutions in 10 countries drawn from all 5 geographical regions across Africa; South Africa, West Africa, East Africa, North Africa and Central Africa. Findings reveal that just like the majority of the African social media population, African universities engage predominantly on Facebook with all 10 universities running an active Facebook handle, showing a $100 \%$ adoption rate.
\end{abstract}

Keywords Marketing, Higher Education, Africa, Facebook, Branding, Social Media

\section{Introduction}

Higher education refers to tertiary level that empowers learners with skills and the recognition of having attained a level of expertise. As of today, the African Development Bank estimates that there are 14 million students in higher education in Africa, representing about $6.4 \%$ of global tertiary education enrolments. Across Africa, only about $7 \%$ of the population that fall within the higher education age bracket are enrolled, necessitating the adoption of branding and marketing strategies as a means of increasing enrolment numbers in institutions across Africa. There are about 1,650 higher education institutions in Africa, many of them facing challenges that require the intervention of stakeholders and the governments to enable learners to fully utilize their opportunities and contribute meaningfully to the workforce (Mba, 2017). While the growth is deemed to be explosive, participation rates are still markedly low compared with the global average necessitating the focus on branding and social media marketing as a means of boosting enrolment numbers across African higher institutions (Kigotho, 2018). Marketing involves getting potential clients or customers interested in your products and services. It is the study of market and consumer behaviours and involves the analysis of company strategies geared towards attracting and keeping customers by delivering quality services. Higher education marketing in Nigeria involves; understanding higher education markets and how students 
institution selection criteria, university branding and international marketing strategies and digital marketing. Media including television, radio and print are some of the mediums employed by HEIs in marketing their institutions. Flyers, calendars, mugs, diaries, t-shirts and billboards are often branded and distributed too. Other ways include Corporate Social Responsibility (CSR), logos, symbols, mottos, sponsorships, websites, blogs, social media and promoting a healthy brand image.

Wootton (2011) posits that for African higher institutions online marketing is pivotal for connecting with prospects, particularly for private or profit-oriented institutions. Data from Facebook shows that it is the top social platform, cornering $60.6 \%$ of internet users (Facebook, 2018).

Social media includes all forms of electronic communication including websites through which users share information, ideas, personal messages, and other content. They are tools that enable users to create content. Effective marketing increase student engagement and drive enrolment. Educators frequently use social media to interact with students on platforms they frequent like; Facebook, Twitter, LinkedIn, Instagram, blogs, websites and YouTube. Social media is the medium of choice for HEIs due to its massive reach, and ease of accessibility. According to Africa Digital Report 2019, out of a total population of 1.304 billion in Africa, $80 \%$ of Africans (1 billion) use mobile phones. Active social media users grew by $13 \%$ ( 25 million people) while those using social media on their devices grew by $17 \%$ (30 million Africans). Social media has a huge potential to grow enrolment numbers, as over $70 \%$ of prospective students utilize it to research college options, enabling means higher education marketers communicate with prospects. This enables higher institutions to create a thriving and recognisable brand that gets the attention of prospects long before the search for enrolment options begins. Consistent interaction on social media apart from driving enrolment numbers up also serves an excellent avenue for an institution to showcase its work, spread information and interact with both current students and alumni. Undergraduates are $44 \%$ higher chance of allowing social media affect their choice of university to study abroad. Over $60 \%$ of all social media activity in Africa was via Facebook, while YouTube cornered almost $17 \%$ of all social media usage in Africa. Pinterest usage was close to $10 \%$, while Twitter usage was just over $8 \%$, and Instagram at just over $6 \%$ with Tumblr rounding up the list at $0.09 \%$ (Africa Digital Report, 2019). University interaction and outreach is also predominantly done via Facebook as well.

Poor funding is the major reason for the poor state of Africa's education system especially its tertiary institutions (Ndujihe, 2018). Due to continued government underfunding HEIs have to raise funds and part of this endeavour includes wooing prospective students thus necessitating the adoption of social media marketing and branding. Online marketing provides a cost-effective alternative in the face of low public funding.

This study investigates Facebook marketing trends in African higher institutions, and its impact on student enrolment. The literature review explores social media forecasts, with emphasis on Facebook and trends over the years as opined by experts. The methodology reveals survey results on the common social media platforms utilized by 10 universities drawn from across Africa, with 2 drawn from each of the 5 geographical regions of the continent. The study points to the exploration of emerging Facebook marketing application as a means of increasing an institution appeal to prospects.

\section{Literature Review}

Africa's economic downturn and the mass exit by professionals hindered the performance of tertiary institutions and their performance as well. Higher education in Africa is below par and sometimes inaccessible, as low as $5 \%$ in some cases (Mba, 2017). This abysmal state of education has resulted in increased rates of migration of in pursuit of better opportunities abroad. Private institutions enrol $25 \%$ of students on the African continent (Campos, 2018). Graduate education continues to contribute negligibly to innovation. Egypt and South Africa are the only universities lauded as top ranking. Sub-Saharan Africa's education sector has seen tremendous growth since the 1970 s. Student enrolment is about 10 million across institutions with only a fraction of these offering graduate programmes and the relevance of this education on offer is highly questionable. According to the Africa Capacity Report 2017, by 2010 enrolment stood at 9.54 million students, with Sub-Saharan Africa registering 6.34 million and North Africa 3.2 million. The need for a thorough overhaul and increasing enrolment drive led to the competitive rebranding and marketing engaged in by some African higher institutions today. Access to education is a major issue facing African nations. Data from UNESCO reveals that Africa has a minute tertiary enrolment rate of just over $12 \%$, far from the $32 \%$ average. In Egypt, tertiary enrolment stands at $33 \%$, while South Africa, Ghana and Nigeria stands at $20 \%, 14 \%$, and $14 \%$ respectively. In Tanzania, it is only $4 \%$ and as low as $2 \%$, in the Republic of Niger. Between 1999 and 2002, enrolment in Africa grew by $170 \%$ according to ICEF Monitor, even though a large number of prospective students still have difficulty finding somewhere to study (QS, 2019).

One in four qualified South African students will be lucky to enrol at a university, but in Nigeria, only one in five applicants will get this opportunity. According to the regulatory body, Inter-University Council for East Africa, 
in 2014, across Burundi, Kenya, Rwanda, Tanzania and Uganda, well over $50 \%$ of graduates were unqualified for the workplace. In Sub-Saharan Africa there are 50\% more students per lecturer than the global average. Many private institutions have been established to meet the need. The Higher Education landscape around the world is changing. Globally, competition for students' enrolment is high, universities are competing within their home market as well as in the international market, and reduced government funding is putting pressure on universities to seek additional income by increasing their student enrolment. African universities are not left out. Universities are striving to understand the stakeholders and strategize on how best to engage with them effectively. The marketing strategies of African universities must consider the unique nature and challenges of African universities with targeted digital marketing and brand management.

\section{The Role of Social Media in Marketing African Higher Institutions}

The competition to capture a sizeable share of the student market is fierce especially for private institutions. Universities are under pressure to provide quality education, maintain a good reputation, keep enrolment figures high, offer top-notch academic programmes and maintain financial stability (Cetin, 2003, p. 57). This has led institutions to adopt strategic marketing plans (Hancock and McCormick, 1996). Social media users make up $45 \%$ of internet user with a whooping figure of 2.5 billion (Emarsys, 2019). Higher education institutions (HEIs) are taking full advantage as evidenced by the fact that $100 \%$ of African universities surveyed operate very active Facebook accounts with a huge following. 7 million advertisers and $93 \%$ of marketers advertise on FB regularly, making it a favourite for advertisers. It has a potential reach of advertising pegged at 1.9 billion and $88 \%$ of users of age 18-29 are on Facebook, making it an ideal medium for universities to connect with and woo their target audienceschool age prospects. $82 \%$ of college graduates are also on Facebook. It has grown into a vital tool in university education, allowing colleges and universities to engage with their audiences effectively. An estimated $100 \%$ of institutions had a social media presence, passing on information about campus scheduled events, engaging with dynamic blog posts, pictures, videos and socializing with virtual tours and other innovative applications (TYFHEM, 2014).

\section{Facebook as a Marketing Tool for African Higher Institutions}

Facebook has 2.45 billion users and is projected to make in global ad revenues in the neighbourhood about $\$ 67.25$ billion in ad revenues in 2019 majorly attributed to the $74 \%$ effectiveness of ads (B2BNews, 2019). $67 \%$ of advertisers consider Facebook to be the most effective platform and Facebook has 7 million advertisers and a potential reach of 1.9 billion and daily visits by 1.62 billion users making Facebook a great potential audience for digital marketing efforts. The app boasts more than 80 million small businesses using Facebook Pages (Facebook, 2018), and is the favourite platform for young adults. $65 \%$ of Facebook users are under the age of 35 (Statista, 2019) bringing them under the age demographic of Millennial and Generation Z - the target audience for tertiary institution marketing campaigns. 1 billion Facebook stories are shared daily and users watch 100 million videos daily making it an excellent marketing channel for institutions that have limited budgets.

In January 2020 , over $60 \%$ of all social media activity in Africa was done via Facebook. This implies that social media is essential to the marketing functions of a HEI which is directly related to an institutions' success and influence educational policies. There is a significant relationship between those logged onto social networks, and the likelihood of applying to the university due to interests generated from these channels (Hayes, Ruschman, \& Walker, 2009). African nations are the fastest growing internet communities with 5 countries doubling their internet populations over the past 12 months, while 9 countries experienced $50 \%$ or more annual growth. One of the reasons why Facebook has become such a huge social network worldwide is due to its mobile accessibility. Content strategy utilizes quality content including short videos, photographs and infographics. Higher education marketers aim to reach the next generation of internet users and prospective students via Facebook (TYFHEM, 2014). This study analysed data from 10 higher institutions in 10 countries drawn from all 5 geographical regions across Africa; South Africa, West Africa, East Africa, North Africa and Central Africa and just like the majority of the African social media population, African universities engage predominantly on Facebook with all 10 universities running an active Facebook handle, showing a $100 \%$ adoption rate.

\section{University of Pretoria (UP)}

The University of Pretoria (UP) is South Africa's largest contact university, with 103, 000 Facebook followers, 99,899likes on their Facebook page and 62,000 students. There are 1357 study programmes. It has an undergraduate pass rate of $83.5 \%$ an $93 \%$ of its students are employed or studying six months after graduation. UP has 267,000 alumni and offers a high level academic excellence. The institution also has a strong social media presence and frequently engages its social media audience and shares information like academic calendar, exam, lecture and holiday dates, enrolment information, competitions and opportunities, funding, social events, milestones and a variety of activities via its Facebook page. 


\section{Namibia University of Science and Technology (NUST)}

NUST is the first university of science and technology in Namibia. It boasts a student population of 10,500, has 43,133 Likes on its Facebook page and 44,174 Facebook followers. NUST is a reputable university famous for its scientific exploits. The university encourages extensive research and creatively supports students. Its mission is to promote national competitiveness by providing multiple opportunities for education, applied research, innovation and service. Its objectives are to focus on a few niche areas and achieve top recognition through applied research and to provide synergy for staff growth around those specific areas while promoting entrepreneurship in a knowledge economy.

\section{Makerere University, Uganda}

Founded in 1922, Makerere University is a co-educational government run, non-profit, public university located in the city of Kampala. It is the top institution in Uganda and $1714^{\text {th }}$ in the world; Makerere University comprises of nine colleges and offers 145 programmes to 36,000 undergraduates and 4,000 postgraduates. Makerere University offers 11 (Eleven) Diplomas and 134 Bachelors degrees and boasts a large staff strength of 1500 . Makerere has 64,387 Followers on Facebook and is pro-active about connecting with its students, prospects and alumni through its Facebook page which is updated with important information on a regular basis.

\section{University of Zambia ( $\underline{\mathrm{UoZ}}$ )}

The institution is a government funded university located in Lusaka, Zambia. It is the largest and oldest learning institution in the country. It was established in 1965 and opened to the public on 12 July 1966 . The motto of the University, SERVICE AND EXCELLENCE tells a story about its goal to provide top-notch education for all.The University of Zambia is a tapestry of cultures, beliefs and religions, ethnic groups, and academic minds, represented by an array of students from various countries in Africa. It creates a conducive environment for students to not only to grow intellectually, but also expand their creativity, faith, political views, social and professional networks. The university has a very active Facebook page with 56,315 followers and a growing student population of 30,000 students.

\section{University of Benghazi}

This institution was founded in December 15,1955 under the name of "Libyan University". In 1976, the institution's name became "University of Garyounis." It has a student population of over 70,000 students, 2000 staff members and officials and over 5,000 employees. After the revolution of Feb. $17^{\text {th }}$ in Libya, the university was renamed "University of Benghazi" in line with rebranding its image. UoB boasts a very prominent social media presence and has 165,000 Facebook followers and 164, 000 likes on its Facebook page.

\section{MISR University of Science and Technology}

This institution is Egypt's first private university, and was established in 1996. It has a growing population of 20,000 students, and is renowned for delivering quality education. Since its inception, MISR university of science and technology has maintained excellent programs, is renowned for its dedication to excellence, and is nationally recognized for its contribution in the field of technology. The university's Facebook page has about 391,000 likes and 394, 000 Facebook followers, and is a meeting point for its teeming population of students and staff.

\section{Obafemi Awolowo University, (OAU) Ile-Ife, Nigeria}

OAU is one of the most popular universities in Nigeria. Founded in 1962 as the University of Ife, it was later renamed as the Obafemi Awolowo University on May 12, 1987, OAU has a student population of 35, 000.11,427 Facebook followers and 11, 155 Facebook page likes. It is also one of Nigeria's first universities and is very popular and highly respected for its high academic standards which it has maintained through the years. The institution frequently updates its Facebook page with campus events and academic information.

\section{University of Liberia (UoL)}

Founded in 1862 as Liberia College and was upgraded to a University in 1951, It is a public institution funded mainly by the Liiberian government. The University has four campuses: Capitol Hill, Fendall, Medical School Fendall, and Starz-Sinji campus located in Sinji, Grand Cape Mount County. It has 18,843 Facebook followers, 17,850 Facebook page likes and 18,753 students. It also has 7 colleges, 4 graduate programs and 3 professional schools. It has a very active Facebook page considering its modest student population.

\section{University of Khartoum (UoK), Sudan.}

The University of Khartoum was formerly known as the University College of Khartoum when the country became independent in 1956. It has since been expanded and boasts 5 campuses and a total of 24,574 students comprising of 16,800 students in 23 faculties, schools and graduate research institutes. The yearly admission rate is 3,500 students, with $55 \%$ of that figure being females. The university is home to 6,000 graduate students and 850 staff members (faculty), 20 research fellows and 500 teaching assistants. The university Facebook page has 171000 likes and 176000 followers which is a large following and a very active Facebook page where it regularly disseminates academic information about the institution's scheduled activities.

University of Addis Ababa, (AAU) Ethiopia 
It was founded in 1950 and formerly named the University College Addis Ababa (UCAA). AAU has more than 53,000 students and 8000 staff (2833 academic and 5385 support staff). In its 13 campuses the university runs 79 undergraduate and 295 graduate programs $(77 \mathrm{PhD}, 177$ masters, 18 specialty and 21 sub-specialty certificates as well as 2 fellowships). AAU has 65519 Facebook page likes and 67540 Facebook followers.

\section{Methodology}

This section describes the methodology adopted for this paper. It also answers the question about the percentage of African higher institutions that have and utilize Facebook as a marketing tool. This section focuses on the sample population and the techniques of collecting an analysing data used.

\section{Research Design}

A descriptive case study was used for this study. It is ideal for this study because it expatiates and reports facts proven by research, which results in the formulation of important principles. This design further describes and explains the level of adoption of Facebook marketing by African HEIs.

\section{Research Population}

A target population comprises of all respondents that the findings can reasonably be generalized to. The respondents of this study were 10 African universities drawn from all 5 geographical regions in Africa whose web portals and Facebook pages provided by the institutions were examined and observed to collect data. Outlined below are the institutions sampled;

Table 1. Displays 10 higher education institutions understudy, indicating their countries and geographical regions

\begin{tabular}{|c|c|c|}
\hline $\begin{array}{c}\text { Geographical } \\
\text { Region }\end{array}$ & $\begin{array}{c}\text { Countries (2 } \\
\text { per region) }\end{array}$ & Universities Selected \\
\hline East Africa & $\begin{array}{c}\text { Zambia } \\
\text { Uganda }\end{array}$ & $\begin{array}{c}\text { University of Zambia } \\
\text { Makerere University }\end{array}$ \\
\hline South Africa & $\begin{array}{c}\text { South Africa } \\
\text { Namibia }\end{array}$ & $\begin{array}{c}\text { University of Pretoria } \\
\text { Namibia University of } \\
\text { Science and Technology }\end{array}$ \\
\hline West Africa & $\begin{array}{c}\text { Nigeria } \\
\text { Liberia }\end{array}$ & $\begin{array}{c}\text { ObafemiAwolowo } \\
\text { University } \\
\text { University of Liberia }\end{array}$ \\
\hline $\begin{array}{c}\text { North Africa } \\
\text { Libya } \\
\text { Egypt }\end{array}$ & $\begin{array}{c}\text { University of Benghazi } \\
\text { Misr University of Science } \\
\text { and Technology }\end{array}$ \\
\hline $\begin{array}{c}\text { Central African } \\
\text { Republic }\end{array}$ & $\begin{array}{c}\text { Sudan } \\
\text { Ethiopia }\end{array}$ & $\begin{array}{c}\text { University of Khartoum } \\
\text { University of Addis Ababa }\end{array}$ \\
\hline
\end{tabular}

Inclusion/ exclusion criteria

Two inclusion criteria were used to screen for relevant studies: (1) published between 2002 and 2020 and (2) contained in the keywords or synonyms related to the research questions: (a) Marketing, (b) higher education; (c) Facebook (d) Africa. The search terms were as follows:

1. Facebook marketing

2. Higher education OR higher institution

3. Africa

4. Facebook

Data screening and extraction

This approach uncovered a total of 10 university websites and their Facebook accounts. 27 papers and articles were reviewed, all published between 2002 and 2020. 2 of the articles were NGO reports on higher education enrolment in Africa, while 25 comprised of primary research studies, theoretical analysis, commentary on higher education in Africa, Facebook, Facebook marketing, branding and African university enrolment data.

\section{Sampling and Sampling Techniques}

Sampling involves the selection of a sample from the entire population. Research by Quartz Africa exploring the 10 countries with the highest population concludes that over 740 of the 1,650 HEIs in Africa are in these countries serving about 660 million people of the 1 billion African population. A sample of 10 universities were randomly drawn from all 5 geographical regions in Africa comprising of; North Africa, West Africa, Central Africa, East Africa, and Southern Africa with 2 institutions per geographical region. Among the institutions are 6 drawn from the top 10 most populated countries with 740 institutions between them so the sample is largely representative. 6 of the top 7 most populated countries also have the highest number of universities in Africa. Simple random sampling was carried out because the sample population was well defined and representative of the entire population.

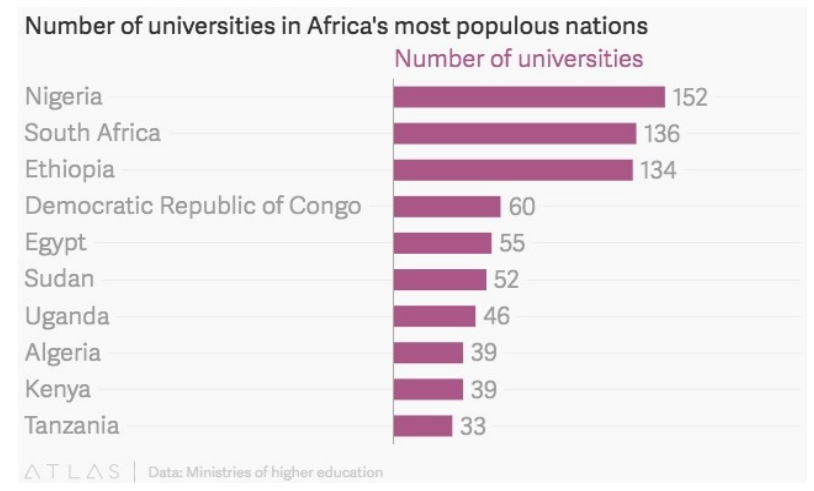

Figure 1. Number of universities in Africa's most populous nations

\section{Data Collection Methods}

Data was collected from websites and Facebook pages of the sampled HEIs. These sources were utilized because they provided sufficient information about the institutions 
and also provided an opportunity for the researcher to observe their perceptions and strategy concerning Facebook marketing.

\section{Data Analysis and Presentation}

Data collected from sampled websites and Facebook pages were analyzed through descriptive narrative analysis and information which was graphed and tabulated.

\section{Findings and Discussion}

This study considered the 10 universities outlined above, drawn from all 5 geographical regions across Africa. All 10 institutions surveyed actively utilize Facebook for their social media marketing which reflects $100 \%$ adoption rate. The study found that universities with a large following on Facebook also had huge student numbers like the University of Pretoria, Makerere University, University of Zambia, University of Benghazi, OAU and AAU which have 62,000, 40, 000, 30,000, $70,000,35,000$ and 53, 000 students respectively. It can be inferred that institutions with high Facebook visibility attracts more prospective students through their social media accounts than their counterparts with less visibility and this attention eventually translates to enrolment and higher student numbers. A study by Sujon, Viney, \& Toker-Turnalar (2018) supports this view as it identifies Facebook as the largest social media for contact with students and prospective students. The findings of this study are also consistent with findings on the use of social media by Polish higher education institutions which found $50 \%$ of the respondents indicating that Facebook is the most important social media communication channel, compared to other channels such as LinkedIn, Youtube, Snapchat, Instagram, and Twitter (Mazurek, Korzynski, \& Gorska, 2019).

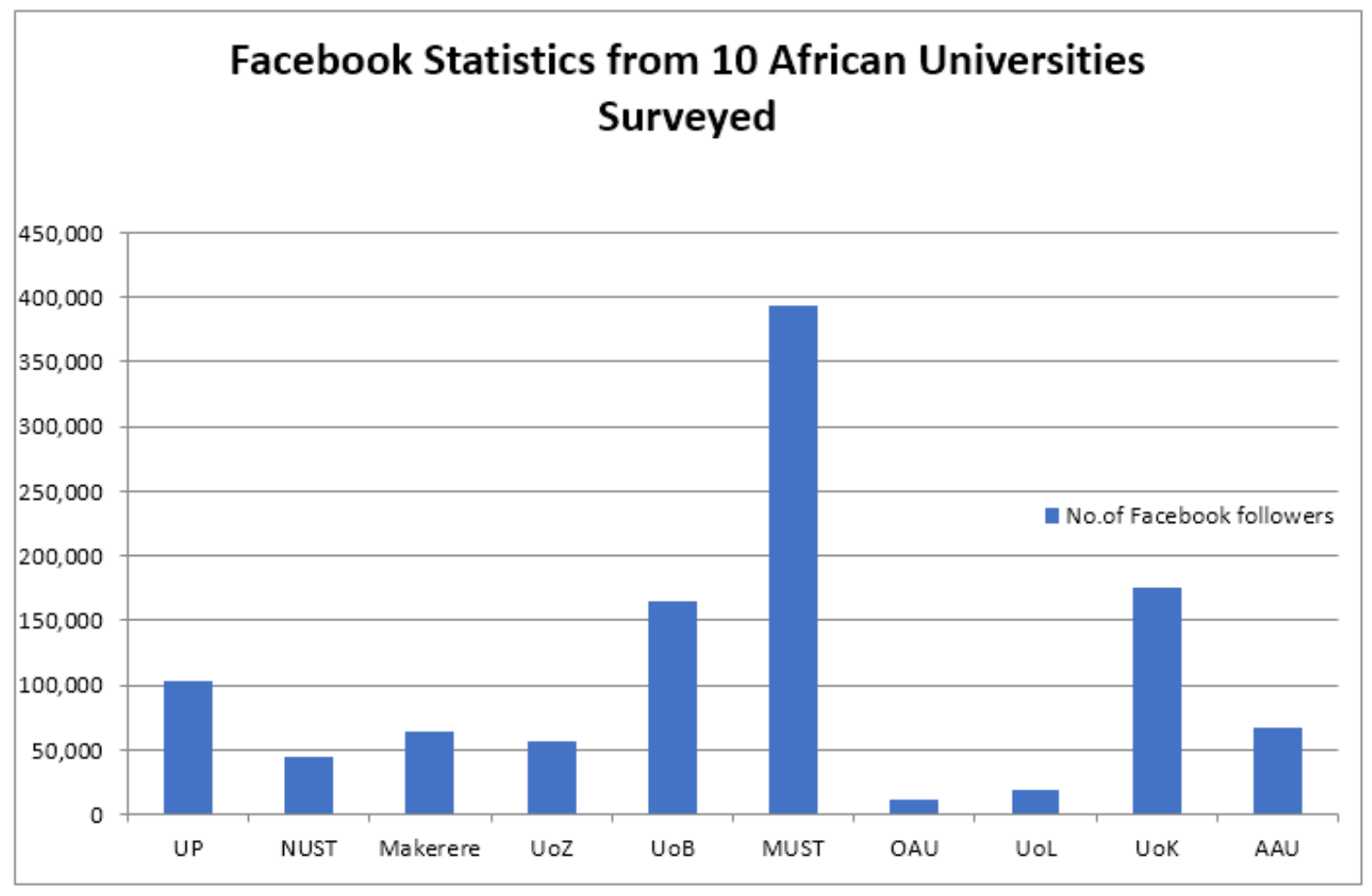

Figure 2. Displays the number of Facebook followers of 10 African universities drawn from all 5 geographical regions in Africa. 
All 10 institutions in this study had Facebook pages with varying degrees of activity. Some were well laid out, interactive, and frequently updated with the latest information on current and future campus events. This includes initiatives ranging from orientation events and pictures, to awards won for feats performed, sporting events, seminars and workshops, scholarship information, vice chancellor's bulletin, science projects, admission information, faculty, and departmental events and similar information. While others were infrequently updated and lacking in content, it was observed that universities with a strong social media presence also had higher student numbers and social media following. According to Ernest \& Ronald (2015), "organisations can communicate with information consumers in its utmost potential. Some organisations not only listen to its customers, but also encourage their customers to talk; therefore work towards engagement." This implies that the more the organisation gets its audience to engage or increase its engagement rate, the higher its visibility rate. Therefore, to increase the degree of activity on these Facebook pages run by these institutions of learning, thereby improving visibility, these pages should be frequently updated ad made interactive. Unlike in the past where new students arrive campus with little or no information about the institution and its activities, Facebook interactions and engagements give them the opportunity of connecting with fellow students online before meeting them. It also gives the student a general orientation of the institution and its activities amongst other things.

With admission information and procedures clearly laid out on their websites and other media, prospective enrolees are more inclined to register at such institutions, as opposed to having to journey all the way to campuses to make enquiries. It was observed that universities with a strong social media presence also had higher student numbers and social media following. Interestingly, Misr University of Science and Technology with just 20, 000 students boast of 394,000 Facebook followers. This figure implies that this institution will record high rates of engagement. As stated by Facebook (2014), engagement is the percentage of people who saw a post, liked, shared, clicked, or commented on it. Comparing these figures from MISR University to other institutions in this study, it is clear that there is a great difference. For example, this study reveals that the University of Khartoum, Sudan has 24,574 students (4,574 students more that MISR university), but has 176,000 Facebook followers ad 171,000 page likes. For the University of Liberia which has 18,753 students, their Facebook page can only boast of 18,843 followers, and 17,850 likes. These figures clearly demonstrate the importance of visibility. Using Facebook, the visibility of higher education institutions in Africa can be increased through engagements on their pages.

\section{Facebook as an Instrument of Attraction in Marketing HEIs}

The role of Facebook in marketing HEIs in Africa involves a public relations technique that differentiates an institution from the competition. Universities maintain lines of communication and interaction to ensure they nurture relationships by consistently reminding prospective students of what they have that their competition lacks. They promote their accomplishments, programs, facilities, values, high quality, affordability, and other strong points. All this is consistently done through the use of various mediums amongst which is Facebook. Among the most important tools for social media branding is a Facebook page. It is usually the first social media platform adopted by African institutions and usually has a larger following than other social media platforms common with universities all over the world. Research by Social Admissions report shows that up to $63 \%$ of students search for and about $60 \%$ follow or like a school they are considering on social media. The report also revealed that one out of every two teen relies on social media in their search for tertiary institutions and African applicants are not left out. There is a huge difference in number of followers and frequency of posting on the Facebook pages of African higher institutions compared with their other social media pages. It is safe to say that Facebook is the primary tool of choice for African HEIs in marketing their institutions.

\section{Conclusion and Recommendation}

This study examined the popularity of Facebook as a marketing tool for HEIs and the relationship between Facebook marketing by HEIs and enrolment rate. The study investigated the role of Facebook marketing in African universities and its effect on building new relationships as well as maintaining effective communication with existing students and alumni. This study concludes that Facebook marketing is a vital means of advertising for tertiary institutions which is indispensable for creating a distinction from the competition and stay in touch with prospective and current students as well as its alumni. To maintain their competitive edge, African higher institutions promote their brand by constantly interacting with students and showcasing their brand and achievements to emphasize their areas of strength. This is predominantly done through the institution's website and social media handles, particularly their Facebook page which has a huge following and is frequently updated with new information. These universities take advantage of their Facebook pages to emphasize on their academic milestones, achievements, upcoming events, unique courses, promos, enrolment information and more. Clubs, alumni groups and academic departments should have their individual pages to enable 
prospective students gain a more detailed insight into their activities. This helps in deciding if the institution is a good match for their lifestyle. Upcoming departmental events are now posted on Facebook pages with people confirming attendance or indicating Interest in attending. HEIs create a presence by creating a Facebook page where they can connect with their community and keep them updated with new information. Institutions have to determine what options are right for their brand campaign or marketing goal out of several advertising options available on Facebook.

HEIs working with programmers, should also explore providing prospects with a customised and personalized virtual tour experience on Facebook, portraying what their day would be like if they were to enrol at the institution. This would provide insight into what academic and after class leisure activities would entail to help them decide if the institution would be a good fit for them. University Facebook pages should also provide tools for real time communication with students to address any questions they might have. The use of podcasts as a marketing tool should also be explored, where a series of podcasts will be shared on Facebook featuring staff members. Facebook apps especially Instagram business profiles spread the word and build brand awareness on Facebook by using the Facebook family of apps, publicize new or upcoming school events, establish a following, reach more people, build a bigger audience of people who are similar to your best customers- in this case, school age millennial. Facebook offers a plethora of advertising solutions to help universities create brand awareness through advertising. Facebook brand awareness ads include video, carousel, and instant experiences. The Reach objective enables Facebook to show any ad type a HEI chooses to the maximum number of people in its target audience, across Facebook, Instagram, Messenger and WhatsApp. Institutions can set the maximum number of times someone can see the ad, and the amount of time between impressions. There is also $\mathrm{Ad}$ buying which enables the institutions choose the way the advert reaches its audience. The Facebook auction delivers the most relevant and highest-performing ads from a campaign. This buying type offers more flexibility for which ads people see. Advertisers that want more control over how often people see their ads and the order in which they see them, select the reach and frequency buying option. Advertisers with an account representative can use Target Rating Points buying. This allows them plan and buy video campaigns using Nielsen-verified TRPs on Facebook and Instagram. The ad recall lift optimisation delivers ads to people who are most likely to refer to them in future. After an advert campaign, advertisers will be able to see a report of the estimated number of people who would remember seeing the advert if asked within two days. You can use the video views optimisation to deliver your ads to people who are most likely to watch your video for specified durations. This optimisation is available with the Video Views objective. Facebook measurement solutions provide free reports about your brand awareness and perception across Facebook platforms and TV. Tools such as brand lift studies, ad recall lift metrics and split testing can help HEIs improve their advertising strategies. Also, Facebook contests should be explored as an effective means of interaction and generating Likes for HEIs pages.

\section{Recommendations for Further Studies}

With Facebook ads raking in $\$ 67.25$ billion in 2019, there are a plethora of new initiatives invented daily to keep up new demands. Some key trends that will feature widely and play key roles in the advertising space in coming years include; AI, Automation \& AR, retargeting, automation tools and virtual tours. Investing in ads is an avenue HEIs need to explore, especially the art of retargeting. Facebook's retargeting features enables the marketer focus on prospects already considering their institution. HEIs and marketers can then create enhance the advantage by pushing ads that project their institutions positively.

In recent times Facebook has embraced artificial intelligence (AI) to enhance advertising on their platform. A few automation tools available for exploration include; Campaign Budget Optimization, Automatic Placements and Dynamic Formats and Ad Creative. Augmented Reality Ads allow users to simulate activities HEIs can explore a virtual campus tour option. Facebook Spaces is an app that will enable users in separate locations meet in a virtual place. It also allows the sharing of different media types in real-time. This platform offers numerous branding options and allows marketers share product information. Leading organizations are already working with Facebook Spaces and exploring this technology that is set to play a huge role in social media marketing in the coming years.

\section{REFERENCES}

[1] Briggs, S. (2007) pg. 705-722. An exploratory study of the factors influencing undergraduate student choice: the case of higher education in Scotland. Retrieved from: https://www.tandfonline.com/doi/full/10.1080/0307507060 1004333 ? src $=$ recsys

[2] B2BNews (2019) 8 Current Facebook Trends \& Forecasts for 2020 You Should Be Thinking About. Retrieved from: https:/financesonline.com/facebook-trends/

[3] Cyberclick (2020) Marketing. Retrieved from:https://www. cyberclick.es/en/marketing

[4] Clement, J. Statistica (2019) Number of Facebook users by age in the U.S. 2018. Retrieved from: https://www.statista.c om/statistics/398136/us-facebook-user-age-groups/ 
[5] Campos, Z. (Forbes 2019) How focusing on education in Africa can help raise young, successful entrepreneurs. Retrieved from:https://www.google.com/amp/s/www.forbe s.com/sites/theyec/2019/10/15/how-focusing-on-education-i n-africa-can-help-raise-young-successful-entrepreneurs/am $\mathrm{p} /$

[6] Dahir, A (2017) Africa has too few universities for its fast growing population. Retrieved from: https://qz.com/africa/8 78513/university-education-is-still-a-dream-many-in-africaare-yet-to-attain/

[7] DMIdaily digest. (2020) THE WHAT, WHY \& HOW OF SOCIAL MEDIA FOR HIGHER EDUCATION. Retrieved from:

https://igitalmarketinginstitute.com/blog/what-why-and-ho w-of-social-media-for-higher-education

[8] Ernest, E., \& Ronald, B. (2015). Investigating Public Universities Facebook Pages: Extent of Users Engagement. Inter. J. Acad. Lib. Info.Sci. 3(2): 31-36.

[9] Emarsys.com (2019) Top 5 Social Media Predictions for 2019. Retrieved from: https://emarsys.com/learn/blog/top5-social-media-predictions-2019/

[10] EWG-L. Higher Education. retrieved from: https://www.wg .aegee.org/ewg/higheredu.htm

[11] Facebook. (2014). How is Engagement Defined. Retrieved from: https://www.facebook.com/help/178043462360087.

[12] Gakinya, P. (2015) The Role of Branding in Attracting Prospective Students to Institutions of Higher Learning: A Case Study of St Paul's University, pg 33. Retrieved from: http://erepository.uonbi.ac.ke/handle/11295/93218

[13] ICEF (2015) African summit calls for major expansion of higher education. Retrieved from: https:/monitor.icef.com/ 2015/03/african-summit-calls-for-major-expansion-of-high er-education/

[14] Kemp, S. (2019) DIGITAL 2019: Global Digital Overview. Retrieved from:

https://atareportal.com/reports/digital-2019-global-digitaloverview

[15] Kigotho, W (2018) Higher education - Caught in a double bind. Retrieved from: https://www.universityworldnews.co $\mathrm{m} /$ post-mobile.php?story $=20180328162530835$

[16] Klassem, M. (2002) pg. 81-85. Relationship marketing on the Internet: The case of top- and lower-ranked US universities and colleges. Retrieved from: https://www.researchgate.net/publication/223874680 Relat ionship_marketing_on_the_Internet_The_case_of_top-_and lower-ranked_US_universities_and_colleges

[17] Mazurek, G., Korzynski, P., Gorska, A. (2019). Social Media in the Marketing of Higher Education Institutions in Poland: Preliminary Empirical Studies. Enterpreneurial Business and Economics Review, 7(1), 117-133. https://doi.org/10.15678/EBER.2019.070107
[18] Mba, J (2017) Challenges and prospects of Africa's higher education. Retrieved from: https://www.globalpartnership.o $\mathrm{rg} / \mathrm{blog} /$ challenges-and-prospects-africas-higher-education

[19] Morsin, M (2019) 10 Social Media Statistics You Need to Know in 2020 [Infographic]. Retrieved from: https://ng.oberlo.com/blog/social-media-marketing-statistic $\mathrm{s}$

[20] Paladan, N.(2018). Higher Education Institutions Embracing Digital \& Social Media Marketing: A Case of Top 25 Universities in Asia \& Africa. Retrieved from: https://mbr.cikd.ca/article_60254.html

[21] Mohsin, M (2019). 10 Facebook Stats Every Marketer Should Know in 2020. Retrieved from: https://ng.oberlo.co $\mathrm{m} / \mathrm{blog}$ /facebook-statistics.

[22] Omnicore (2019) Facebook by the Numbers. Retrieved from:

https://www.omnicoreagency.com/facebook-statistics/

[23] QS Symonds (2019). Africa's Higher Education Landscape..Retrieved from:https://www.qs.com/africas-hig her-education-landscape/

[24] Siu, E (2020) 5 Facebook Ads Trends You Can't Ignore in 2020. Retrieved from: https://www.singlegrain.com/facebo ok/facebook-ads-trends-2020/

[25] Sujon, Z., Viney, L., \&Toker-Tunalar, E. (2018). Domesticating Facebook: The Shift from Compulsive Connection to Personal Service Platform. Social Media + Society, 4(4),https://doi.org/10.1177/2056305118803895

[26] The African Capacity Building Foundation, Africa Capacity Report ACR 2017. Retrieved from: https://www.acbf-pact.o $\mathrm{rg} /$ what-we-do/how-we-do-it/knowledge-learning/africa-ca pacity-report/africa-capacity-report-acr-2017

[27] Thomas, J. Doug., Mary M. (2009) Social Networking as an Admission Tool: A Case Study in Success. Retrieved from:

https://www.researchgate.net/publication/233307483 Socia 1_Networking_as_an_Admission_Tool_A_Case_Study_in Success

[28] Turner, E. (2017) Social Medias Influence on college Choice retrieved from:https://www.google.com/url?q=https ://files.eric.ed.gov/fulltext/EJ1158257.pdf\&sa=U\&ved=2ah UKEwipmc i7YXoAhWEqaQKHaLlAhIQFjAAegQICBA B\&usg $=$ AOvVaw0ea-2ldgINt-IYL8MxL1cz

[29] TEN YEARS OF FACEBOOK IN HIGHER EDUCATION MARKETING (2014). Retrieved from: https://www.higher -education-marketing.com/blog/ten-years-facebook-highereducation-marketing

[30] WARC. (2019) Davidson, Neil. retrieved from: https://www.warc.com/newsandopinion/opinion/how_can you_make_your_marketing_more_effective_in_africa $/ 31 \overline{85}$

[31] You build the brand. Facebook helps you tell everyone about it. Retrieved from: https://web.facebook.com/busines s/goals/build-awareness?_rdc=1\&_rdr 